\title{
Preliminary Study of Serum Calcium And Phosphorus Levels And Normal Hematologic Parameters in Clydesdale Horses
}

\author{
Daniela Mello Vianna Ferrer ${ }^{1}$; Nelson Elias Soffe Filho² \\ Paula de Mattos Guttmann ${ }^{1}$; Denise de Mello Bobány ${ }^{1}$ \\ ${ }^{1}$ Unifeso- Centro Universitario Serra dos Orgãos-Teresopolis-Rio de Janeiro-Brasil \\ ${ }^{2}$ Veterinary practicioner
}

\begin{abstract}
The limited knowledge about the Clydesdale horse biology interferes with their feeding management, since nutritional requirements for these horses are used by analogy with other cold bloods breeds, like Breton horses. Likewise, from the clinical standpoint, there is little informations about diseases specific to this breed. Therefore, this study aims to establish normal serum calcium and phosphorus levels, as well as to describe preliminary hematologic patterns for Clydesdale horses in soil, pasture, management and climate conditions in the Rio de Janeiro region. Blood samples were collected by jugular vein punction from fifteen Clydesdale horses (10 female and 5 male)stabled at a farm in Rio de Janeiro. Hematologic results differed from literature results, but were similar to horses with lymphatic temperament. In comparison to reference values for horses in general, serum calcium values were lower in Clydesdale horses, while serum phosphorus values were similar.
\end{abstract}

Keywords: Clydesdale horses, hematology, blood, metabolism, Ca-P

\section{Introduction}

Equineshave been through numerous changes throughout their evolution over millions of years, and nowadays there are many different breeds[1,2].Clydesdales are heavy and powerful horses, with large strides and big hooves, perfect to work in the soft soil of Scottish rough grounds. Their general characteristics are common to traction or draft horses and distinct from other breeds. Due to their good reputation,the use of the breed soon spread all over Scotland and north of England [3,4,5]. From the year 1850 on, good quality stallions and mares were exported mostly to Australia and New Zealand, but also to England, United States and Canada, and then to Russia, Italy, Austria and countries from South America [4,5].

There was a decline in the breed during the 1960's and beginning of 1970's and in 1975 the Rare Breed Survival Trust classified the Clydesdales as "vulnerable" [5]. However, the breed regained popularity at the end of the XXth century, and although substituted by the tractor in most of the farms, this breed still works in agriculture and forestry, where tractors are not able or not desired[4,5].Horses whose ancestrals belong to the Arab, Quarter horse and Thoroughbred breeds are called hot bloods. The crossbreds (created by breeding of many breeds and other crossbreds) and the ponies are called draft horses or cold bloods horses. However, there are crossbreds with either temperaments, which probably depends on how much influence they have from their ancestrals [6].

Horses can be classified as cold bloodedbreeds or hot blooded breeds, from the hematology point of view. Hot blooded breeds have higher hematologic parameters and are more sensitive to stress by management or manipulation[7].The number of circulating red cells in horses is not stable due to spleen reserves [8]. Kramer[6]quotes that spleen contracts in situations of fear, emotions or exercise, leading to an increase of up to $30 \%$ in packed cell volume (PCV) and total red cell count. In horses, the red cell volume remains within rigid limits, even during disease, so the mean corpuscular volume (MCV) and mean globular volume (MGV) are stable. Most certainly, an increase in PCV occurs due to an increase in number of cells, rather than increase of cellular volume [8].Blood test results are interpreted in accordance to reference values obtained from research in healthy animals, and some breeds can influence in the results[6,9].Correct interpretation of results requires knowledge of physiologic variations that may happen due to many factors, such as management, breed, age, sex and physiologic state of the animal (pregnancy, lactation, moment of sample collection), as well as environmental conditions like temperature, altitude and air humidity[10].

Kramer[6]states thaterythrogrammean and standard deviation reference values for Clydesdale horses $\operatorname{are} 7,30 \times 10^{6} / \mu \mathrm{L} \pm 0,87$ for RBC; $12,4 \mathrm{~g} / \mathrm{dl} \pm 1,1$ for hemoglobin ; 33,0 \% $\pm 3,0$ for PCV and mean reference values for MCV 44,6 fl and CHCM 38,1\%.The calcium has a very important and diverse role in physiology, and is the most abundant mineral in the body [9]. Kerber [11] states that phosphorus is of vital importance in growing and health of the animals, since it is an important constituent of teeth and bone, together with calcium.According to Coles [12], approximately $99 \%$ of calcium and $80-85 \%$ of phosphorus are in the skeleton and teeth. Although extracellular fluid $\mathrm{Ca}$ is essential,only a small percentage is in the blood. 
Kaneko,Harvey,Bruss[13] describe the following reference values for horses in general: Calcium (Ca) 2.80-3.40 (3.10 \pm 0.14$) \mathrm{mmol} / \mathrm{L}$ and Phosphorus $(\mathrm{P}) 1.00 \pm 1.81 \mathrm{mmol} / \mathrm{L}$. Mundim[14] states that calcium and phosphorus mean and standard deviation reference values for Breton foals older than 18 months are $8.94 \pm 1.54$ $\mathrm{mg} / \mathrm{dL}$ and $4.53 \pm 0.63 \mathrm{mg} / \mathrm{dL}$, respectively.Self-control mechanism of mineral ingestion in horses is not very efficient, which may lead to Calcium x Phosphorus relation unbalancing [15].This study aims to establish normal serum $\mathrm{Ca}$ and $\mathrm{P}$ values, as well as to describe preliminary hematologic patterns in the Clydesdale horse, living in management and climate conditions of Rio de Janeiro region.

\section{Material and Method}

The paper "Preliminary study of seric calcium and phosphorus and normal hematologic parameters in Clydesdale horses", protocol number 0270/09, was approved by the UNIFESO Ethics and Animal Use Commission in November 26, 2009.Fifteen Clydesdale horses (10 females and 5 males) with ages ranging from 18 months to 8 years were used in the study. The horses were stabled in a farm in Rio de Janeiro, in a semiintensive system, where they were kept part of the day in the pasture and part of the day in stables. They were fed alfalfa hay and a commercial horse feed. Linseed and mineral salt with amino acids were supplied in order to guarantee nutritional requirements. All animals were vaccinated and dewormed in a regular basis. Ectoparasites were controlled.Blood was collected by jugular vein punction in EDTA and biochemistry tubes. The samples were processed at the Laboratory of the teaching hospital of the Veterinary Medicine School of UNIFESO. All analysis were done according to Schalm;Jain; Carrol[16]. The following analysis were performed:

1. Erythrogram: Red blood cell (RBC - hemocytometer), Hemoglobin concentration (Hb cianometahemoglobin - spectrophotometry), Packed cell volume (PCV -microhematocrit). Mean corpuscular volume (MCV), Mean corpuscular hemoglobin concentration(MCHC), and Mean corpuscular hemoglobin $(\mathrm{MCH})$ were calculated according to the following formula:

2. $\mathrm{MCV}=\underline{\mathrm{PCV} \times 10} ; \mathrm{MCH}=\underline{\mathrm{Hb} \times 10}$ andMCHC $=\underline{\mathrm{Hb} \times 10}$.

RBCRBC PCV

3. Leukogram: white blood cell count (WBC - hemocytometer) and differential leukocyte count.

4. Platelets.

5. Qualitative analysis of red and white cells was done by May-Grünwald-Giemsa stain blood smears (MGG) [17].

6. Serum calcium (Ca) and phosphorus $(\mathrm{P})$ were determined by spectrophotometry.

7. Mean values, standard deviation, and confidence interval were statistically analyzed.

\section{Results and Discussion}

Different breeds can influence hematologic results, although there is scarce data specifically about Clydesdale breed [18].

3.1 Hematologic Parameters - erythrogram and leukogram

Individual results for erythrogram and leukogram are described in Tables 1 and 2, respectively, with mean values in Table 3.

Table 1:Erythrogram values in Clydesdale horses $(\mathrm{n}=15)$

\begin{tabular}{|c|c|c|c|c|c|c|c|c|}
\hline Animal & Sex & $R B C$ & $H b$ & $P C V$ & $M C V$ & $\mathrm{MCH}$ & $\mathrm{MCHC}$ & Platelets \\
\hline 1 & $\mathrm{M}$ & 5,8 & 11,0 & 34 & 58 & 18,9 & 32 & 228 \\
\hline 2 & $\mathrm{~F}$ & 5,8 & 10,0 & 32 & 55 & 17,2 & 31 & 288 \\
\hline 3 & $\mathrm{~F}$ & 5,8 & 11,0 & 34 & 58 & 18,9 & 32 & 208 \\
\hline 4 & $\mathrm{~F}$ & 5,6 & 11,0 & 33 & 58 & 19,6 & 33 & 244 \\
\hline 5 & $M$ & 5,9 & 10,0 & 32 & 54 & 16,9 & 31 & 158 \\
\hline 6 & $\mathrm{~F}$ & 4,8 & 9,0 & 28 & 56 & 18,7 & 33 & 250 \\
\hline 7 & $\mathrm{~F}$ & 6,0 & 11,0 & 35 & 58 & 18,3 & 31 & 176 \\
\hline 8 & $\mathrm{~F}$ & 5,9 & 11,0 & 34 & 57 & 18,6 & 32 & 194 \\
\hline 9 & $\mathrm{~F}$ & 5,9 & 10,0 & 32 & 54 & 16,9 & 31 & 218 \\
\hline 10 & $\mathrm{M}$ & 6,4 & 12,0 & 38 & 59 & 18,7 & 33 & 187 \\
\hline 11 & $\mathrm{~F}$ & 6,0 & 11,0 & 35 & 58 & 18,3 & 33 & 210 \\
\hline 12 & $\mathrm{~F}$ & 5,1 & 9,0 & 29 & 56 & 17,6 & 31 & 252 \\
\hline 13 & $\mathrm{M}$ & 6,0 & 8,8 & 26 & 43 & 14,6 & 33 & 208 \\
\hline 14 & $\mathrm{M}$ & 6,1 & 11,0 & 35 & 57 & 18,0 & 31 & 189 \\
\hline 15 & $\mathrm{~F}$ & 6,0 & 11,0 & 34 & 57 & 18,3 & 32 & 164 \\
\hline Mean & & 5,8 & 10,5 & 33 & 56 & 18,0 & 32 & 212 \\
\hline Standard Deviation & & 0,4 & 0,9 & 3 & 4 & 1,2 & 1 & 36 \\
\hline Lowerlimit & & 5,6 & 10,0 & 31 & 54 & 17,4 & 31 & 193 \\
\hline Higherlimit & & 6,0 & 10,9 & 34 & 58 & 18,6 & 32 & 230 \\
\hline \multicolumn{4}{|c|}{ RBCRed Blood Cells x $10^{6} / \mathrm{mm}^{3}$} & \multicolumn{5}{|c|}{ MCVMean Corpuscular Volume fl } \\
\hline
\end{tabular}


Preliminary study of serum calcium and phosphorus levels and normal hematologic parameters in

\begin{tabular}{|l|l|}
\hline HbHemoglobin g/dl & MCHMean Corpuscular Hemoglobinpg \\
\hline PCVPackedCells Volume \% & $\begin{array}{l}\text { MCHCMean Corpuscular Hemoglobin } \\
\text { Concentration } \%\end{array}$ \\
\hline Platelets $\times 10^{3} / \mathrm{mm}^{3}$ & \\
\hline
\end{tabular}

Table 2:Leukogram values in Clydesdale horses $(\mathrm{n}=15)$

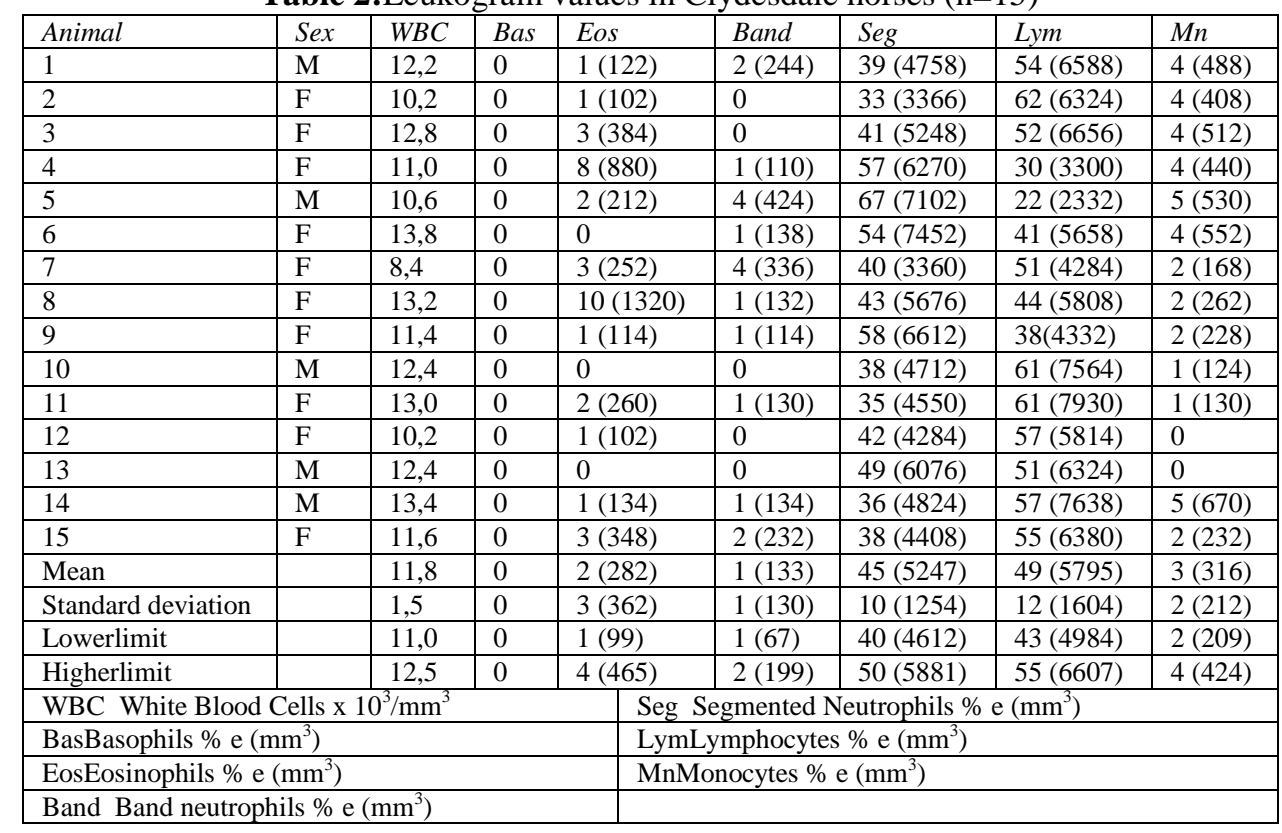

Table 3: Mean values of erythrogram and leukogram in Clydesdale horses $(\mathrm{n}=15)$

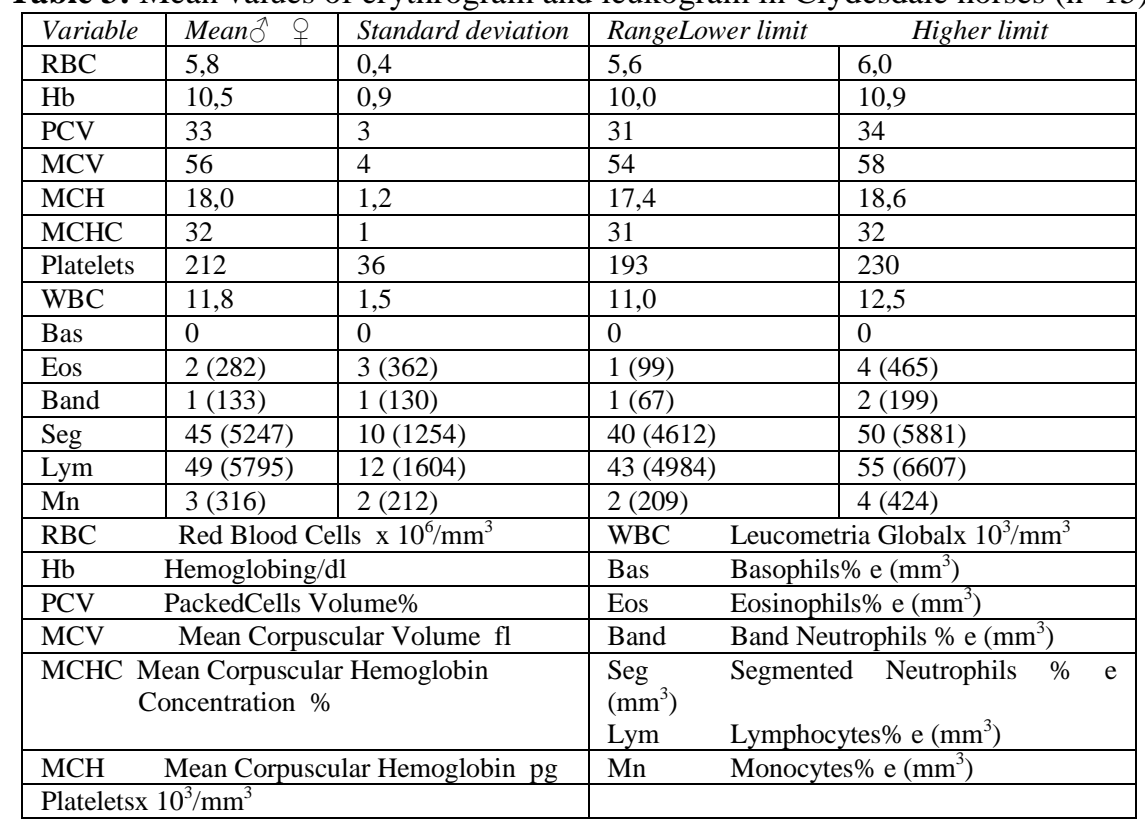

Mean results for RBC, hemoglobin and MCHC were $5.8 \times 10^{6} / \mu \mathrm{L} \pm 0.4,10.5 \mathrm{~g} / \mathrm{dL} \pm 0.9$ and $32 \%$, respectively, which were all below the values described by Feldman; Zinkl; Jain[18] for the Clydesdale horse. PCV mean was $33.0 \% \pm 3.0$, which was the same as described by Feldman; Zinkl; Jain [18].And MCV mean result was 56,0 fl, higher than described by Feldman; Zinkl; Jain [18] for Clydesdale horses. MCV mean value was 18,0pg, higher than the value described by Feldman; Zinkl; Jain [18] for mixed breeds. RBC, Hb and PCV are within the normal limits for cold blooded horses, such as described by Kramer[6].The authors referenced in this paper evaluated animals bred in cold climate countries, differently from this study, and according to Mundim et al. [10] this can interfere on feeding and physical activity, which may explain differences in the values found in this study.Temperament influences on hematologic results, where cold bloodedbreeds present mean values lower than hot bloodedbreeds, according to Kramer [6]. The mean values for RBC $(5,8$ $\left.\mathrm{x} 10^{6} / \mu \mathrm{L}\right), \mathrm{Hb}(10,5 \mathrm{~g} / \mathrm{dL})$ and PCV $(33,0 \%)$ found in this study for the Clydesdale breed are within the normal 
limits described by the aforementioned authors for cold bloodedbreeds(RBC 5,5 - 9,5 x10 $/ \mu \mathrm{L}, \mathrm{Hb} 8,0-14,0 \mathrm{~g} / \mathrm{d}$ $\mathrm{L}$ and PCV 24,0 - 44,0\%). White Blood Cellsmean value was $11.8 \times 10^{3} / \mathrm{mm}^{3}$, which is within the normal limits $\left(6.0\right.$ a $\left.12.0 \times 10^{3} / \mathrm{mm}^{3}\right)$ for cold blooded breeds, according to Kramer[6], but closer to the higher limit. Differential leukocyte count results were: $1 \%$ band neutrophils, $45 \%$ segmented neutrophils, $49 \%$ lymphocytes, $3 \%$ monocytes and $2 \%$ eosinophils, and were also within the normal limits for cold blooded breeds, according to Kramer[6], except for lymphocytes, which are higher and in accordance with hot blooded horses.

\subsection{Serum Biochemistry - Serum Calcium and Phosphorus}

All the results for serum $\mathrm{Ca}$ and $\mathrm{P}$, as well as mean,standard deviation and confidence interval are described in Table 4. Ca average result was $8.0 \pm 0.6 \mathrm{mg} / \mathrm{d} \mathrm{L}$ and $\mathrm{P}$ was $3.4 \pm 0.5 \mathrm{mg} / \mathrm{dL}$, which were lower then results found for Breton foals older than 18 months $(8.94 \pm 1.54 \mathrm{mg} / \mathrm{dL}$ and $4.53 \pm 0.63 \mathrm{mg} / \mathrm{dL}$, respectively) by Mundin[14]. However, the horses used in this study are older than the Breton foals in Mundin'sstudy. Kaneko;Harvey;Bruss [13]decribe higher values for $\mathrm{Ca}$ and $\mathrm{P}(12,4 \pm 0,56$ e 4,0 $\pm 7,24)$ than the ones obtained in this study.When comparing with the data published by Coles [12] for equine species in general, which was $12.8 \mathrm{mg} / \mathrm{dL}$ for calcium and phosphorus to $4.2 \mathrm{mg} / \mathrm{dL}$ (1 to 5 young equines years); $2.85 \mathrm{mg} / \mathrm{dL}$ (adult equine), calcium levels are higher than those found in this work $(8.0 \mathrm{mg} / \mathrm{dL})$. However, the levels of phosphorus (3.4 $\mathrm{mg} / \mathrm{dL}$ ) are on average between equines young and old, and in this work was not taken into consideration the age of the animals.The average value for the concentration of calcium found in this study was $8.0 \pm 0.6 \mathrm{mg} / \mathrm{dL}$. This value is lower than that found in the literature varies within the $10.215 .1 \mathrm{mg} / \mathrm{dL}$ according to the data of the research of Reed and Bayly [9], Lumdsen, Rowe and Mullen [19]; Rose and Hodgson [20] and Coffman [21].

Table4: Values of serum calcium and phosphorus of Clydesdale horses $(\mathrm{n}=15)$

\begin{tabular}{|l|l|l|l|}
\hline Animal & Sex & $\begin{array}{l}\text { Calcium }(\mathrm{Ca}) \\
\text { mg/dl }\end{array}$ & $\begin{array}{l}\text { Phosphorus }(\mathrm{P}) \\
\text { mg/dl }\end{array}$ \\
\hline Number1 & $\mathrm{M}$ & 9,2 & 3,2 \\
\hline Number2 & $\mathrm{F}$ & 7,7 & 3,1 \\
\hline Number3 & $\mathrm{F}$ & 7,4 & 3,5 \\
\hline Number4 & $\mathrm{F}$ & 8,0 & 3,6 \\
\hline Number5 & $\mathrm{M}$ & 7,7 & 3,1 \\
\hline Number6 & $\mathrm{F}$ & 8,8 & 3,0 \\
\hline Number7 & $\mathrm{F}$ & 7,6 & 3,2 \\
\hline Number8 & $\mathrm{F}$ & 7,2 & 3,3 \\
\hline Number9 & $\mathrm{F}$ & 7,9 & 3,0 \\
\hline Number 10 & $\mathrm{M}$ & 8,4 & 3,3 \\
\hline Number 11 & $\mathrm{F}$ & 8,2 & 3,4 \\
\hline Number 12 & $\mathrm{F}$ & 8,2 & 3,5 \\
\hline Number 13 & $\mathrm{M}$ & 7,7 & 5,0 \\
\hline Number 14 & $\mathrm{M}$ & 7,2 & 2,9 \\
\hline Number 15 & $\mathrm{F}$ & 8,1 & 3,2 \\
\hline Mean & & 8,0 & 3,4 \\
\hline Standard deviation & & 0,6 & 0,5 \\
\hline Lowerlimit & & 7,7 & 3,1 \\
\hline Higherlimit & & 8,2 & 3,6 \\
\hline
\end{tabular}

\section{Conclusions}

Hematology results from Clydesdale horses obtained in this study are similar to other draft horse breeds. Although still preliminary, this data is important for the process of establishing reference values for the Clydesdale horses.

\section{References}

[1]. G. H. Waring. Horse behavior. 2 (New York: Noyes Publications, 2003). 426.

[2]. J.F.Vieira. Equídeos. (Joinvile-SC: Clube de Autores, 2008). 33-36.

[3]. C. Silver.Tudo sobre cavalos: um guia mundial de 200 raças. 3 (São Paulo: Martins Fontes, 2000).11-12, 222-223.

[4]. B.L. Hendricks. International Encyclopedia of Horse Breeds. (Oklahoma: University of Oklahoma Press, 2007). 132-134.

[5]. Clydesdale Horse Society of Great Britain and Ireland. Clydesdale Stud Book, Vol. 1-30 (California-USA: Clydesdale Horse Society of United Kingdom of Great Britain and Ireland., 1908, 2009).

[6]. J.W. Kramer. Normal hematology of the horse, in: B. F. Feldman, J. G.Zinkl, N. C. Jain. Schalm's veterinary hematology. 5(Baltimore - USA: Lippincott Williams \& Wilkins, 2000). 1069-1074.

[7]. C. E. K. Garcia-Navarro. Manual de hematologia veterinária.2(São Paulo: Varela, 2005). 206.

[8]. G. P. Carlson. Testes de química clínica, in: B. P. Smith. Tratado de medicinainterna de grandes animais. Vol.1(São Paulo: Manole, 1993) 395-426.

[9]. S. M. Reed, W. M.Bayly.Medicina Interna Equina. (Rio de Janeiro: Guanabara Koogan, 2000). 938.

[10]. A. V. Mundim,A. A. Teixeira, J. A.Galo, F. S. R. Carvalho. Perfil bioquímico e osmolaridade sanguínea de equinos utilizados para trabalho em centros urbanos. BioscienceJournal,20(1), 2004, 135-142. 
[11]. C. E.Kerber.Métodos para avaliação da mineralização óssea de equinos em crescimento. Revista de Educação Continuada do CRMV-SP, 2(I), 1999.17-25.

[12]. E. H. Coles.Patologia Clínica Veterinária.3(São Paulo: Ed. Manole, 1984). 76-77, 300-305.

[13]. J. J. Kaneko, J. W. Harvey, M. L. Bruss. Clinical Biochemistry of domestic animals. 5(London: Academic Press, 1997$) .932$.

[14]. A. V. Mundim.Perfil bioquímico sérico em potros bretão postier e cães doberman em fase de crescimento e de cabras saanen nos diferentes estádios de lactação.doctoral diss., Universidade Federal de Uberlândia, MG, 2008.

[15]. L. C. V. O.Ramos,W. M. Ferreira, L. C.Gonçalves,F. J. Gazzinelli.Hidroxiprolina e fosfatase alcalina como parâmetros fisiológicos indicadores do status metabólico do cálcio e do fósforo em equinos. Revista Acadêmica, 5(4), 2007, 359-368.

[16]. O. W. Schalm,N. C. Jain, E. J. Carrol.Veterinary Hematology. 3(Philadelphia: Lea \&Febiger, 1975$) .807$.

[17]. J. Rullier, A. Parodi.Laboratoire et diagnostic en MédicineVétérinaire.(Paris: VigotFères. 1968 ). 711.

[18]. B. F. Feldman,J. G. Zinkl, N. C.Jain.Schalm's veterinary hematology. 5(Baltimore - USA: Lippincott Williams \& Wilkins, 2000). 1344 .

[19]. J. H. Lumsden,R. Rowe, K.Mullen. Hematology and biochemistry reference values for the light horse. CanadianJournalofComparative Medicine, (44), 1980, 32-42.

[20]. R. J. Rose, D. R. Hodgson. Hematology and biochemistry,in: D. R. Hodgson, R. J. Rose. The atlhetic horse: principles and practice of equine sports medicine.(Philadelphia: Saunders, 1994). Cap.5, 63-78.

[21]. J. R.Coffman.Equine Clinical Chemistry and Pathophysiology,(Kansas - USA: Veterinary Med. Publishing Company, 1981 ). 275. 